ks. Dariusz Lipiec ${ }^{1}$

Katolicki Uniwersytet Lubelski

\title{
Przeciwdziałanie
}

\section{marginalizacji niepełnosprawnych w życiu wspólnotowym Kościoła}

Pojęcie marginalizacji w naukach społecznych nie doczekało się dotychczas jednej definicji, którą przyjęli wszyscy badacze zajmujący się tą problematyką. Są oni jednakże zgodni, że zjawisko marginalizacji dotyczy grup społecznych, których pozycja w społeczeństwie została zdegradowana do stanu peryferyjnego wskutek zdominowania ich przez grupy centralne. Znajdowanie się w pozycji zmarginalizowanej ma konsekwencje w mniejszym dostępie - w stosunku do grup centralnych do różnorakich dóbr, takich jak: władza polityczna, dobra kulturalne czy ekonomiczne. Będąc w sytuacji ograniczonego wyboru, grupy marginalizowane pozostają w sytuacji mniejszego lub większego przymusu, co z kolei skutkuje mniejszymi możliwościami korzystania z dóbr będących do dyspozycji grup społecznych znajdujących się w centrum życia społecznego.

Marginalizacja ma charakter procesu rozciągniętego w czasie, krótszym lub dłuższym. „Konsekwencją długotrwałej marginalizacji

1 Dariusz Lipiec - ks. dr hab., prof. KUL zatrudniony w Katedrze Teologii Pastoralnej Społecznej na Wydziale Teologii KUL. E-mail.dlipiec@kul.pl. 
społecznej jest wykluczenie społeczne. Przybiera ono formę ograniczenia ról społecznych, utraty sensu życia, braku nadziei na poprawę swojej sytuacji" ${ }^{2}$. Należy jednak zauważyć, że nie we wszystkich sytuacjach marginalizacja skutkuje wykluczeniem społecznym, lecz przyjmuje formę ignorowania grup społecznych i przebywania przez nie z dala od głównego nurtu życia społecznego.

Zjawisko marginalizacji opisywane jest przede wszystkim w kontekście całości życia społecznego określonych społeczności. Są to najczęściej społeczności zamieszkujące państwa lub społeczności lokalne. Marginalizacją mogą być dotknięte także osoby lub ich grupy we wspólnocie Kościoła. Jedną z takich grup są niepełnosprawni, którzy z powodu posiadanych dysfunkcji mają utrudniony dostęp do dóbr oferowanych przez Kościół, a przede wszystkim napotykają trudności w aktywnym zaangażowaniu się w jego życie wspólnotowe.

Pojęcie „życie wspólnotowe” nie zostało jednoznacznie określone w teologii katolickiej. Najczęściej używane jest w odniesieniu do podmiotowego zaangażowania katolików we wspólnocie kościelnej i obejmuje wszelkie formy aktywności, we wszystkich dziedzinach życia tej wspólnoty. W niniejszym opracowaniu określenie „życie wspólnotowe” odnosi się przede wszystkim do zaangażowania katolików w zakresie funkcji pasterskiej Kościoła.

\section{Marginalizacja i integracja niepełnosprawnych we wspólnocie parafialnej}

Chociaż zasadniczą rolę w budowaniu wspólnotowości kościelnej odgrywa diecezja jako Kościół partykularny, nad którym pasterską pieczę sprawuje biskup, będący następcą apostołów i członkiem kolegium biskupiego, to „parafia jest miejscem spotkania posłannictwa całego Kościoła z wiarą jednostek, rodzin i małych grup religijnych. Zatem zadania parafii związane są z jej charakterem jako lokalnej wspólnoty, która

2 I. Fajfer-Kruczek, Wykluczenie społeczne osób niepełnosprawnością w środowisku lokalnym, Katowice 2015, s. 44. 
łączy element osobistego zaangażowania z formą wspólnoty eklezjalnej. W poszczególnej wspólnocie parafialnej Kościół ukazuje się w sposób konkretny, ponieważ tutaj codzienne życie wiernych spotyka się z realną obecnością Odkupiciela”.

Nauczanie Soboru Watykańskiego II wskazuje, że wspólnotowość parafii ma charakter wertykalny i horyzontalny. Oznacza to, iż jest ona wspólnotą ludzi z Bogiem i między sobą. To zjednoczenie między wierzącymi dokonuje się poprzez słuchanie i głoszenie słowa Bożego, sprawowanie kultu i modlitwę oraz realizację miłości braterskiej (zob. KL 42; DA 10). Te aspekty wspólnotowości wzajemnie się przenikają, tworząc wielowymiarową wspólnotę chrześcijan.

Do budowania wspólnoty parafialnej wezwani są wszyscy ochrzczeni na mocy sakramentów inicjacji chrześcijańskiej, a w ich liczbie także osoby niepełnosprawne. Mają one bowiem w Kościele pełną podmiotowość wynikającą z przyjęcia tych sakramentów. Oznacza to, że nie mogą one być jedynie adresatami działalności innych, ale same - na miarę własnych możliwości - mają angażować się w życie i budowanie wspólnoty parafialnej (por. DA 30).

Przez wiele wieków osoby niepełnosprawne były postrzegane głownie jako beneficjenci miłości wspólnoty parafialnej. W dobie przedsoborowej wskazywano proboszczom, by mieli spis osób niepełnosprawnych w parafiach i otaczali je duszpasterską troską. Rozumiano ją zasadniczo w dwójnasób: była to troska o życie duchowe, głównie sakramentalne, oraz przychodzenie im ze wsparciem materialnym. Troska o życie duchowe sprowadzała się często do udzielania niepełnosprawnym sakramentów, zwłaszcza spowiedzi i Komunii Świętej. Miało to miejsce zasadniczo w okresie adwentu i Wielkiego Postu i łączone było z rekolekcjami parafialnymi. Praktyka taka wynikała z faktu, że osoby niepełnosprawne traktowane były na równi z chorymi, ponieważ świadomość odrębności niepełnej sprawności, jak również jej specyfiki była na stosunkowo niskim poziomie, także wśród duszpasterzy. Niepełnosprawnych, podobnie jak chorych, przywożono do kościoła, aby mogli oni przystąpić

3 R. Kamiński, Parafia miejscem realizacji duszpasterstwa, w: Teologia pastoralna, t. 2, red. R. Kamiński, Lublin 2002, s. 31. 
do sakramentów. Tych zrewalidowanych w najmniejszym stopniu pozostawiano w domu i tam byli oni odwiedzani przez duchownych. Działo się tak również dlatego, że rodziny wstydziły się swych niepełnosprawnych członków. Osoby takie były bowiem przez wielu postrzegane jako niepełnowartościowe, zaś takie przekonanie o niepełnosprawnych było przenoszone na całą rodzinę.

Osoby niepełnosprawne w parafii były także beneficjentami pomocy materialnej. Najczęściej parafianie spotykali je żebrzące przed kościołami, obok sierot, osób starszych i bezdomnych. Parafie jednak miały obowiązek pomocy potrzebującym, a w ich liczbie także niepełnosprawnym. Parafie duże, zwłaszcza w miastach, prowadziły tzw. szpitale, pełniące w różnych okresach historycznych rolę hospicjów, domów pomocy społecznej, szpitali we współczesnym rozumieniu i inne role. Od czasów starożytności, a w Polsce od czasu chrztu, Kościół miał obowiązek przekazywać część swoich dochodów na działalność charytatywną. Pewne znaczenie miała również doraźna pomoc materialna, zwłaszcza rzeczowa, dla niepełnosprawnych i ich rodzin. Ze względu na brak obowiązku, w wielu wypadkach pomoc ta nie była rejestrowana, dlatego jej rozmiar i zakres są trudne do precyzyjnego określenia. Tak dzieje się również współcześnie, ponieważ proboszczowie nieczęsto prowadzą rejestry osób, do których kierowana jest pomoc, ani rodzajów tej pomocy.

Spisy niepełnosprawnych w parafiach służyły nie tylko ewidencji takich osób, ale wiązały się z zaleceniem odwiedzania ich przez proboszczów. Chodziło o odwiedziny duszpasterskie poza wizytą kolędową, którą duchowni mieli obowiązek odbywać każdego roku. Wskazywano, aby proboszczowie odwiedzali rodziny niepełnosprawnych częściej, najlepiej systematycznie, udzielając wsparcia duchowego im i ich bliskim, a przede wszystkim, by znali ich sytuację egzystencjalną. Uznawano, że odwiedziny kolędowe jeden raz w roku nie dają podstawy do odpowiedniej znajomości uwarunkowań życiowych niepełnosprawnych parafian $^{4}$.

4 Por. T. Fedorowicz, Uwagi o duszpasterstwie niewidomych, Warszawa 1960, s. 1-4 [mps w archiwum Krajowego Duszpasterstwa Niewidomych w Warszawie]. 
Nauczanie Kościoła współczesnego wskazuje na konieczność włączania osób niepełnosprawnych w życie wspólnoty eklezjalnej 5 . Parafia stwarza możliwości różnorakiego ich podmiotowego zaangażowania, w zakresie każdej funkcji podstawowej. Niepełnosprawni mogą pełnić funkcje liturgiczne: ministranta, lektora, psałterzysty, mogą śpiewać w scholach i chórach parafialnych, być nadzwyczajnymi szafarzami Najświętszego Sakramentu. Mogą angażować się w katechezę parafialną oraz przygotowanie dzieci, młodzieży i dorosłych do sakramentów, pracować w poradniach życia rodzinnego. Istnieje możliwość zaangażowania się osób z niepełną sprawnością w różnorakie gremia i zespoły parafialne, takie jak: parafialna rada duszpasterska i ekonomiczna, parafialny zespół Caritas. Osoby niepełnosprawne mogą także angażować się w różnorakie przedsięwzięcia o charakterze społecznym i kulturalnym. Jedynym ograniczeniem w tym względzie jest to spowodowane skutkami niepełnosprawności.

Brak wyczerpujących badań dotyczących zaangażowania osób niepełnosprawnych w życie lokalnych wspólnot kościelnych. Badania prowadzone przez ks. Dariusza Lipca wśród niewidomych w Polsce wykazały, że bardzo niewielki ich odsetek zasiada w parafialnych radach duszpasterskich $^{6}$. Z badań przeprowadzonych przez ks. Wiesława Przygodę wynika, że ponad jedna czwarta (26,5 proc.) członków parafialnych zespołów Caritas i charytatywnych ma 66 lat i więcej; pozwala to przypuszczać, że wśród nich są także osoby z niepełną sprawnością, związaną z wiekiem senioralnym. Nie jest znany odsetek niepełnosprawnych zaangażowanych $\mathrm{w}$ zrzeszenia religijne na terenie parafii. Cząstkowe badania wykazały, że niewielki odsetek osób niepełnosprawnych uczestniczących w dedykowanym im duszpasterstwie nadzwyczajnym udziela się we własnych wspólnotach parafialnych ${ }^{8}$. Należy również zauważyć,

Zob. Dokument Stolicy Apostolskiej na Międzynarodowy Rok Osób Upośledzonych, „Ateneum Kapłańskie” 76 (1984) z. 1, s. 8-19.

6 Por. D. Lipiec, Duszpasterstwo niewidomych i słabowidzacych w Polsce. Studium teologicznopastoralne, Lublin 2011, s. 260.

7 W. Przygoda, Apostolski wymiar wolontariatu charytatywnego w Polsce. Studium teologicznopastoralne na podstawie badań wolontariuszy z parafialnych zespołów Caritas, Lublin 2012, s. 23. ${ }^{8}$ Por. D. Lipiec, Duszpasterstwo niewidomych..., dz. cyt., s. 260. 
że bardzo niewielki odsetek osób z niepełną sprawnością jest beneficjentem pomocy charytatywnej w swoich parafiach. Według ks. Witolda Janochy tylko 8 proc. badanych takich osób otrzymało jakąkolwiek pomoc w swojej parafii. 3,4 proc. respondentów wskazało na pomoc duchową, a 1,5 proc. na pomoc materialną. Były to: artykuły żywnościowe, odzież, sprzęt AGD. Częściej pomoc taką otrzymywali mieszkańcy parafii miejskich niż wiejskich'.

Działania zmierzające do integracji niepełnosprawnych w parafii powinny przebiegać dwutorowo. Jeden kierunek działalności pastoralnej dotyczy ogółu parafian, drugi natomiast osób obarczonych niepełnosprawnością. Duszpasterstwo skierowane do wszystkich parafian ma za cel ich formację do włączania niepełnosprawnych w główny nurt życia wspólnotowego. Dotyczy ona w pierwszej kolejności poznania osób niepełnosprawnych we własnym otoczeniu oraz zrozumienia specyfiki ich niesprawności i przełamania lęku przed nimi. Przezwyciężenie błędnych stereotypów dotyczących takich osób pomaga w zrozumieniu ich funkcjonowania w życiu społecznym oraz dostrzeżeniu możliwości ich podmiotowego zaangażowania we wspólnocie parafialnej. Formacja parafian obejmuje także dawanie im bodźców do wychodzenia ku niepełnosprawnym z takimi propozycjami.

Dostarczanie bodźców do angażowania się w życie parafii jest konieczne także w stosunku do samych niepełnosprawnych. Tworzenie atmosfery życzliwości wokół nich może ich ośmielać, konieczna jest jednak zachęta i wskazanie konkretnych form działania. Początkiem ich aktywnej działalności może być oferta uczestnictwa w pielgrzymce parafialnej, a jeśli to konieczne, także zaoferowanie pomocy osoby asystującej. Duszpasterze mogą również zachęcać do udziału we wspólnym przedsięwzięciu, takim jak jasełka, święta parafialne i im podobne ${ }^{10}$.

9 W. Janocha, Religijność osób niepetnosprawnych i ich rodzin. Studium socjologiczno-pastoralne, Lublin 2011, s. 211-212.

10 D. Lipiec, Duszpasterstwo niepetnosprawnych w parafii, „Perspectiva” 8 (2009) nr 2, s. $120-122$. 


\section{Działalność pastoralna diecezji \\ na rzecz integracji niepełnosprawnych}

Ograniczanie pracy z niepełnosprawnymi, jakie stało się udziałem Kościoła w Polsce po II wojnie światowej, skłoniło go do poszukiwania nowych form zaangażowania się na rzecz takich osób. Już w latach 50. $\mathrm{XX}$ wieku podjęto próby stworzenia struktur równoległych do instytucji państwowych, pozostających w służbie niepełnosprawnym. Powoływano ośrodki duszpasterstwa nadzwyczajnego, dedykowanego osobom z różnorakimi rodzajami upośledzenia. Ośrodki te znajdowały się głównie na dwóch szczeblach działalności kościelnej: ogólnopolskim i diecezjalnym. Na szczeblu ogólnopolskim kierowali nimi mianowani przez prymasa Polski krajowi duszpasterze poszczególnych środowisk niepełnosprawnych, przed nim składający sprawozdania ze swej działalności, natomiast na szczeblu diecezjalnym na czele tzw. duszpasterstw stali diecezjalni duszpasterze, ustanawiani przez biskupów diecezjalnych. Struktury organizacyjne, mające zasięg ogólnopolski, służyły inspirowaniu, organizowaniu i koordynowaniu działalności pastoralnej.

Powołanie ośrodków duszpasterstwa nadzwyczajnego, dedykowanego osobom z określonego rodzajuniepełnosprawnością, w takim kształcie było uwarunkowane także ich pozycją w ówczesnym społeczeństwie oraz ich potrzebami. System wspierania i opieki państwa nad niepełnosprawnymi miał charakter, który można określić jako segregacyjny. Szkolnictwo, zarówno podstawowe, jak i ponadpodstawowe, oparte było o system ośrodków szkolno-wychowawczych. Dotyczy to zwłaszcza niewidomych, głuchych i niepełnosprawnych intelektualnie. Podobnie system zatrudnienia niepełnosprawnych opierał się w znacznym stopniu na spółdzielniach inwalidów, gdzie często pracowały osoby z jedną dominującą kategorią niepełnosprawności. Taki system wychowania, kształcenia i zatrudnienia niepełnosprawnych sprzyjał ich osobistemu rozwojowi, jaki nie mógł być ich udziałem w środowiskach, z których się wywodzili. Mankamentem takiego podejścia do tych osób było ich izolowanie - w pewnym stopniu - od głównego nurtu życia społecznego, co sprzyjało powstawaniu u nich tzw. mentalności getta. 
Przebywanie niepełnosprawnych we własnych środowiskach miało także walory, spośród których wyróżniają się: poczucie bycia rozumianym i akceptowanym przez osoby podobne sobie i rozumiejące specyfikę niepełnosprawności, otrzymywanie pomocy adekwatnej do potrzeb oraz relacje osobiste, które nawiązywały się poprzez długotrwałe przebywanie w grupie osób znanych sobie. Takie walory środowisk, w których przebywały osoby niepełnosprawne z określonymi rodzajami inwalidztwa, stały się podstawą do stworzenia tzw. duszpasterstw niepełnosprawnych. Duszpasterze często wnikali w takie środowiska, prowadząc w nich działalność pastoralną. Miała ona za cel uzupełnienie duszpasterstwa zwyczajnego, zwłaszcza w zakresie przepowiadania słowa Bożego w sposób dostosowany do potrzeb i możliwości osób niepełnosprawnych, a także sprawowania sakramentów, przede wszystkim Eucharystii i spowiedzi.

Działalność pastoralna adresowana do osób o określonym rodzaju niepełnosprawności ma także walory wspólnototwórcze. W pierwszej kolejności służy uświęcaniu środowisk niepełnosprawnych. Jak inne środowiska, mają one swoje określone problemy, zaś duszpasterstwo służy ich rozwiązywaniu w oparciu o zasady ewangeliczne. Ponadto spotkania duszpasterskie służą pogłębianiu integracji środowisk i umacnianiu więzi między ich członkami.

Wspólnototwórczy wymiar działalności pastoralnej przejawia się także w integrowaniu niepełnosprawnych oraz ich rodzin i bliskich. Niepełnosprawność i wynikające z niej problemy dotyczą nie tylko osób nią dotkniętych, lecz także członków ich rodzin, przyjaciół, sąsiadów itd. Osoby te nie zawsze rozumieją specyfikę niepełnosprawności, potrzeby osób nią dotkniętych i dlatego nierzadko zachowują mniejszy lub większy dystans wobec nich. Uczestnicząc w duszpasterstwie niepełnosprawnych, osoby z ich otoczenia uczą się specyfiki ich życia oraz nabywają umiejętności przychodzenia im z pomocą. W ten sposób również stają się rzecznikami ich sprawy w środowiskach ich zamieszkania, pracy, w kręgach szeroko rozumianej rodziny, przyjaciół i znajomych.

Duszpasterstwo nadzwyczajne, dedykowane poszczególnym grupom niepełnosprawnych, służy także integracji całego środowiska. W inicjatywach pastoralnych, takich jak: spotkania duszpasterskie, pielgrzymki, rekolekcje, dni skupienia i inne, uczestniczą zarówno osoby 
z niesprawnością skupione w placówkach państwowych, społecznych i ich organizacjach, oraz takie, które nie mają formalnych relacji ze środowiskiem. Ze względu jednak na specyfikę niesprawności oraz problemy i potrzeby z niej wynikające, szukają one relacji z osobami sobie podobnymi. Osoby takie przychodzą nierzadko ze swymi bliskimi, zarówno ze względu na własne, jak również ich potrzeby. W ten sposób krąg osób związanych ze sobą się powiększa, tworząc swego rodzaju grupę wsparcia. Duszpasterze zwracają jednak uwagę, że tym, co gromadzi ludzi we wspólnotę, nie jest niepełnosprawność, lecz osoba Jezusa Chrystusa. W ten sposób nadają oni kierunek działalności pastoralnej oraz rozwoju społeczności osób zebranych wokół niepełnosprawnych, przeciwstawiając się m.in. tendencjom do tworzenia ekskluzywnych grup, zamkniętych na świat zewnętrzny ${ }^{11}$.

Współczesne tendencje, zmierzające do jak najdalej idącej integracji niepełnosprawnych w społeczeństwie, osłabiły ich środowiska i zmieniły spojrzenie na szkolnictwo, pracę i życie społeczne osób z niepełną sprawnością. Wiele osób niepełnosprawnych, zwłaszcza młodych, nie tylko nie szuka, ale unika osób sobie podobnych, starając się na wszelkie możliwe sposoby upodobnić do sprawnych członków społeczeństwa. Dotyczy to także życia we wspólnotach eklezjalnych. Niechętnie angażują się w duszpasterstwo nadzwyczajne im dedykowane, kierując się bardziej ku swoim parafiom. Ich życie religijne we wspólnotach parafialnych przypomina jednak życie, jakie wiodą w społeczności świeckiej. Nie wszyscy oni są w pełnej możności uczestnictwa w życiu wspólnot eklezjalnych, mimo pomocy ze strony środowiska. Innym powodem dystansowania się od życia wspólnotowego we własnych parafiach są procesy sekularyzacyjne, które środowiska niepełnosprawnych dotykają w podobny sposób, jak środowiska ludzi sprawnych.

Przeciwdziałaniu marginalizacji niepełnosprawnych, zarówno w społeczeństwie, jak i we wspólnocie Kościoła, służą inicjatywy z zakresu szeroko rozumianej posługi charytatywnej. Diecezja dysponuje zasobami ludzkimi i materialnymi przekraczającymi zasoby parafii, dlatego na jej

11 D. Lipiec, Duszpasterstwo niepełnosprawnych $w$ diecezji, „Roczniki PastoralnoKatechetyczne" 4 (2012), s. 76-78. 
terenie możliwe jest podejmowanie działalności w zakresie rehabilitacji medycznej, zawodowej i społecznej. Do najczęściej spotykanych należą: warsztaty terapii zawodowej, zakłady aktywizacji zawodowej, poradnie, ośrodki informacji dla niepełnosprawnych, wypożyczalnie sprzętu rehabilitacyjnego i im podobne. Caritas diecezjalne udzielają także wsparcia materialnego osobom niepełnosprawnym i ich rodzinom. Coraz rzadziej jest to pomoc finansowa, częściej natomiast w postaci różnorakiego sprzętu: AGD, rehabilitacyjnego czy środków czystości ${ }^{12}$.

Wychodząc naprzeciw potrzebom osób niepełnosprawnych i ich rodzin, a także uwzględniając współczesne uwarunkowania społeczno-prawne ich funkcjonowania, w diecezjach powołuje się katolickie stowarzyszenia niepełnosprawnych. Dedykowane są one zarówno niepełnosprawnym w ogólności, jak i osobom o określonym rodzaju niesprawności. Ich zasadniczym celem jest szeroko rozumiana integracja społeczna i eklezjalna takich osób. Ważnym elementem ich funkcjonowania jest formacja religijna członków i ich rodzin. Chodzi bowiem o ukazanie nadprzyrodzonego wymiaru niepełnosprawności i integracji osób nią obarczonych.

\section{Niepełnosprawni we wspólnotach życia}

Specyficznym miejscem przeciwdziałania marginalizacji osób niepełnosprawnych są wspólnoty życia. Można je określić mianem domowego Kościoła, ponieważ swoją strukturą i funkcjonowaniem przypominają rodziny. Wspólnoty te można określić jako chrześcijańskie z kilku powodów. Powstały one z inspiracji ewangelicznej. Motywem ich powoływania była obecność osób niepełnosprawnych, które postrzegane są jako najsłabsi członkowie społeczności ludzkiej i wspólnoty chrześcijańskiej. Obecność takich osób odwołuje się do przykazania miłości bliźniego, będącego podstawową zasadą życia społecznego chrześcijan. specyfika niepełnosprawności oraz jej stopień wskazują na konieczność

12 Por. W. Przygoda, Posługa charytatywna Kościoła wobec osób niepetnosprawnych, „Homo Dei" 74 (2004) nr 1, s. 66-70. 
zwrócenia się ku takim osobom, zaś radykalizm ewangeliczny skłania do całkowitego oddania się na służbę im. Podobne ideały przyświecają wolontariuszom (socjuszom) decydującym się na życie we wspólnocie $\mathrm{z}$ niepełnosprawnymi ${ }^{13}$.

Dostrzeżenie Chrystusa w osobach niepełnosprawnych nie jest aktem jednorazowym, poprzedzającym decyzję o założeniu wspólnoty życia lub wstąpieniu do niej. Odkrywanie Chrystusa w takich osobach jest udziałem wolontariuszy przez cały czas życia we wspólnocie. Odkrywają oni Jego obecność w takich osobach jako znak Jego obecności w świecie i w Kościele. Proces coraz głębszego odkrywania Chrystusa w niepełnosprawnych sprzyja również odkrywaniu Jego obecności w sobie i skłania do coraz głębszego jednoczenia się z Nim. Osoby sprawne odkrywają również znaczenie ubóstwa i słabości człowieka, które może być ubogacone i wypełnione jedynie obecnością i działaniem Boga. Sprzyja to coraz głębszemu rozumieniu sensu i wartości egzystencji ludzkiej na ziemi, a także dążeniu do pełnego zjednoczenia z Chrystusem w wieczności ${ }^{14}$.

Wspólnoty życia budowane są wokół Chrystusa, który gromadzi osoby niepełnosprawne i sprawne. On jest osią ich życia, wokół której ono się toczy, On także daje siłę do działania wspólnocie i poszczególnym jej członkom. Wprawdzie wspólnoty życia otwarte są na socjuszy o innym światopoglądzie niż chrześcijański, a nawet na osoby określające siebie jako niewierzący, to przebywanie w komunii z niepełnosprawnymi wymaga nieustannego potwierdzania dokonanego wyboru i zadawania odpowiedzi na dość często powracające pytanie o motywację do zaangażowania wymagającego poświęcenia ${ }^{15}$.

Wspólnoty życia cechują się podmiotowością wszystkich ich członków. W odniesieniu do osób niepełnosprawnych podmiotowość oznacza nie tylko traktowanie ich jako osób obdarzonych przez Boga godnością, a więc podmiotowo. Podmiotowość niepełnosprawnych $\mathrm{w}$ tych

13 D. Bartosz, Pozostać wiernym pierwotnym ideałom, w: Połaczeni w słabości, red. A. Kalinowski, Kraków 2006, s. 43-45.

14 E. Kalinowski, Zasady funkcjonowania Wspólnot Życia z Osobami Niepełnosprawnymi, w: Połaczeni w słabości, dz. cyt., s. 16.

15 Por. E. Jaruzelska, Relacje we wspólnocie miejscem przemiany, w: Połaczeni w słabości, dz. cyt., s. 73-80. 
wspólnotach oznacza także ich oddziaływanie na osoby sprawne zaangażowane we wspólnotach, przede wszystkim na wolontariuszy. Oddziaływanie to dokonuje się głównie poprzez samą obecność, która skłania sprawnych do zadawania sobie fundamentalnych pytań dotyczących egzystencji ludzkiej. Dotyczy to zwłaszcza pytań o wartość i sens ludzkiego życia, a także o jego cel doczesny i ostateczny. Bliskość osób niepełnosprawnych i słabych sprzyja również odkrywaniu własnej niedoskonałości, a zwłaszcza słabości duchowej w postaci egoizmu. Przebywanie we wspólnocie życia sprzyja więc pogłębianiu wiary oraz życia duchowego, zwłaszcza pracy nad słabościami ${ }^{16}$.

Chociaż istnieje kilka typów wspólnot życia, wszystkie one cechują się znacznym podobieństwem do domów rodzinnych ${ }^{17}$. Relacje w nich panujące przypominają relacje w rodzinie, co znajduje swoje odzwierciedlenie w określaniu niepełnosprawnych mianem dzieci. Także wymóg, aby wolontariusze byli osobami bezżennymi, wskazuje na całkowite zorientowanie ich na osoby niepełnosprawne i na charakter relacji istniejących między nimi. Dotyczy to również małżeństw zaangażowanych we wspólnotach.

Podobieństwo domów-wspólnot życia do rodziny oznacza, że są to wspólnoty zbawienia ${ }^{18}$. Podobnie jak w rodzinach chrześcijańskich, tak i we wspólnotach tych życie religijne wyznaczane jest rytmem czasu. W niektórych domach praktykuje się wspólną modlitwę i czytanie Pisma Świętego, a w wielu celebruje się obchody roku liturgicznego. Religijny charakter nadaje się świętowaniu rocznic i jubileuszy członków wspólnoty oraz samej wspólnoty.

Chrześcijański charakter wspólnot życia polegający na słuchaniu i rozważaniu słowa Bożego, wspólnej modlitwie i świętowaniu oraz głęboko

16 E. Kalinowski, Zasady funkcjonowania Wspólnot Życia z Osobami Niepełnosprawnymi, dz. cyt., s. 15 .

17 Są to: domy rodzinne, domy chronione oraz domy chronione z osobami niepełnosprawnymi - E. Kalinowski, Zasady funkcjonowania Wspólnot Życia z Osobami Niepełnosprawnymi, dz. cyt., s. 12 .

18 Por. A. Żarow-Nitoń, Ruch „Wiara i Światło” w służbie rewalidacji społecznej osób znacznie niepełnosprawnych intelektualnie, w: Kościót w stużbie osób niepełnosprawnych, red. W. Kubik, Kraków 2003, s. 57-60. 
pojętym praktykowaniu miłości braterskiej sprawia, że są one swego rodzaju Kościołami domowymi i wspólnotami zbawienia. Przyczyniają się one do coraz głębszego wrastania we wspólnotę Kościoła lokalnego, a przez niego Kościoła powszechnego. Wspólnoty życia mają także walor apostolski. Poprzez świadectwo chrześcijańskiego życia i miłości oddziałują one na otoczenie, motywując jego członków do przyjmowania chrześcijańskiego stylu życia.

\section{Zakończenie}

Kościół katolicki podejmuje wielorakie wysiłki na rzecz przeciwdziałania marginalizacji niepełnosprawnych w swojej wspólnocie. Działania te skierowane są zarówno do ogółu wierzących, jak i do osób dotkniętych niepełną sprawnością oraz ich bliskich. Duszpasterstwo zwyczajne zmierza przede wszystkim do umożliwienia takim osobom podmiotowego zaangażowania we wspólnotach lokalnych oraz podejmuje działania zmierzające do formacji wszystkich członków wspólnoty wierzących. Nowego znaczenia nabiera duszpasterstwo nadzwyczajne, które stanowi uzupełnienie duszpasterstwa zwyczajnego. Jego celem jest coraz częściej pomoc osobom niepełnosprawnym w wyjściu z zamkniętego kręgu osób podobnych sobie i w podejmowaniu różnorakich zadań w Kościele. Oryginalną inicjatywą podejmowaną przez chrześcijan jest tworzenie wspólnot życia. Otwierają one zarówno niepełnosprawnych, jak i socjuszy na Boga i Kościół, pozwalając odkrywać własne specyficzne miejsce w jego wspólnocie. 


\section{Summary}

Przeciwdziałanie marginalizacji niepełnosprawnych w życiu wspólnotowym Kościoła

Od początku swego istnienia Kościół podejmował opiekę nad ludźmi niepełnosprawnymi. Jednym $\mathrm{z}$ jej elementów jest troska o to, by angażowali się podmiotowo w życie jego własnej wspólnoty. W artykule zostały ukazane dążenia współczesnego Kościoła do aktywnego angażowania osób niepełnosprawnych. W pierwszej części zostały przestawione wysiłki zmierzające do ich zaangażowania w rodzinnych parafiach. Druga część zawiera obraz duszpasterstwa nadzwyczajnego i troski o włączanie niepełnosprawnych w życie Kościoła na szczeblu diecezjalnym i ponaddiecezjalnym. Trzecia część ukazuje wspólnoty życia z niepełnosprawnymi, funkcjonujące na podobieństwo Kościoła domowego. W zakończeniu wskazano na możliwości dalszej pracy z niepełnosprawnymi, zmierzającej do ich aktywizacji we wspólnocie Kościoła.

Słowa kluczowe: przeciwdziałanie marginalizacji, marginalizacja, inkluzja

\section{Counteracting Marginalization of Disabled People in the Community Life} of the Church

Since the beginning, the Church has been taking care of disabled people. One of the examples is the care concerning the engagement of the disabled into the life of their community. The article presents the efforts of the contemporary Church for the active engagement of the disabled. The first part contains the description of the efforts which aim at engaging the disabled into the life of their parishes. The second part consists of the image of the extraordinary pastoral care and of the care for engaging the disabled into the life of the Church at the diocesan level as well as at higher levels. The third part presents the communities with disabled people which function similarly to the domestic Church. The ending presents indications for the further cooperation with disabled people, which aims at their active engagement in the community of the Church.

Keywords: counteracting marginalization, marginalization, inclusion 


\section{Bibliografia}

Dokument Stolicy Apostolskiej na Międzynarodowy Rok Osób Upośledzonych. „Ateneum Kapłańskie” 76 (1984) z. 1, s. 8-19.

Bartosz D., Pozostać wiernym pierwotnym ideałom, w: Połaczeni w słabości, red. A. Kalinowski, Kraków 2006, s. 41-52.

Fajfer-Kruczek I., Wykluczenie społeczne osób niepetnosprawnościa w środowisku lokalnym, Katowice 2015.

Fedorowicz T., Uwagi o duszpasterstwie niewidomych, Warszawa 1960 [maszynopis w archiwum Krajowego Duszpasterstwa Niewidomych w Warszawie].

Janocha W., Religijność osób niepetnosprawnych i ich rodzin. Studium socjologiczno-pastoralne, Lublin 2011.

Jaruzelska E., Relacje we wspólnocie miejscem przemiany, w: Połaczeni w słabości, red. A. Kalinowski, Kraków 2006, s. 73-80.

Kalinowski E., Zasady funkcjonowania Wspólnot Życia z Osobami Niepełnosprawnymi, w: Połaczeni w słabości, red. A. Kalinowski, Kraków 2006, s. 11-16.

Kamiński R., Parafia miejscem realizacji duszpasterstwa, w: Teologia pastoralna, t. 2, red. R. Kamiński, Lublin 2002, s. 11-71.

Lipiec D., Duszpasterstwo niepetnosprawnych w parafii, „Perspectiva” 8 (2009) nr 2, s. $107-124$.

Lipiec D., Duszpasterstwo niewidomych i słabowidzacych w Polsce. Studium teologicznopastoralne, Lublin 2011.

Lipiec D., Duszpasterstwo niepetnosprawnych $w$ diecezji, „Roczniki PastoralnoKatechetyczne" 4 (2012), s. 65-79.

Przygoda W., Posługa charytatywna Kościoła wobec osób niepetnosprawnych, „Homo Dei" 74 (2004) nr 1, s. 59-70.

Przygoda W., Apostolski wymiar wolontariatu charytatywnego w Polsce. Studium teologicznopastoralne na podstawie badań wolontariuszy z parafialnych zespołów Caritas, Lublin 2012.

Żarow-Nitoń A., Ruch "Wiara i Światto” w służbie rewalidacji społecznej osób znacznie niepełnosprawnych intelektualnie, w: Kościół w stużbie osób niepełnosprawnych, red. W. Kubik, Kraków 2003, s. 7-62. 